Univerzitet u Beogradu
Poljoprivredni fakultet
Institut za poljoprivrednu tehniku
Naučni časopis
POLJOPRIVREDNA TEHNIKA
Godina XLV
Broj 1, 2020 .
Strane: $77-87$

\title{
BENEFIT COST ANALYSIS OF ADOPTING A MODIFIED CASSAVA ATTRITION PEELING MACHINE IN MECHANIZED CASSAVA PROCESSING
}

\author{
Edeh J. $\mathrm{C}^{* 1}$ and Lewachi A. A ${ }^{1}$ \\ ${ }^{1}$ Department of Mechanical Engineering, \\ College of Engineering and Engineering Technology, \\ Michael Okpara University of Agriculture, Umudike, Nigeria
}

\begin{abstract}
This paper assessed the benefits of adopting a modified cassava attrition peeling machine in mechanised Cassava (Manihot Esculenta) processing. The parameters evaluated and compared between the modified cassava attrition peeling machine, existing attrition peeler and manual peeling technique include the specific energy consumption, peeling efficiency, flesh loss, throughput capacity, payback period and benefit cost ratio. The results showed that the improved machine has a payback period of one year and four months with Benefit Cost Ratio, BCR of 2.56. Significant improvements on its performance parameters was evident with $43 \%$ increase in peeling efficiency, $74.8 \%$ increase in throughput, $67 \%$ tuber flesh recovery, $12 \%$ energy cost savings and $10.6 \%$ reduction in specific energy consumption over the existing attrition peeler.
\end{abstract}

Keywords: Modified Cassava attrition peeling machine, payback period, benefit cost ratio, energy cost savings, performance parameter.

\section{INTRODUCTION}

Cassava, Manihot Esculenta, is an annual crop cultivated in the tropical and subtropical regions for its roots high carbohydrate content as a major source of edible starchy food.

\footnotetext{
*Corresponding Author. E-mail address.engredehjohnc@gmail.com
} 
It is utilized extensively for human and livestock consumption as well as for other industrial products such as starch and alcohol production (El-Sharkawy and Cock, 1987). Its roots in addition to being rich in starch contain calcium, phosphorus and vitamin $\mathrm{C}$ in significant traces of $16 \mathrm{mg} / 100 \mathrm{~g}, 27 \mathrm{mg} / 100 \mathrm{~g}$ and $20.6 \mathrm{mg} / 100 \mathrm{~g}$ respectively (Ravindran, 1992). Though poor in protein and other nutrients they are generally composed of $70 \%$ moisture, $24 \%$ starch, $2 \%$ fibre, $1 \%$ protein and $3 \%$ other nutrient (CSIR 2017).

The commercial potential of cassava is currently under utilized in Nigeria, even though she is one of the largest producer in the world with approximately 45 million tones of tubers produced annually, accounting for $19 \%$ of world production (Adekanye et al., 2013).

This is attributed to inadequate mechanization of the processing operation. Egbeocha et al. (2016) posited that the best form of cassava tuber preservation and the reduction of post-harvest losses has been its immediate processing into various shelf stable products. Several operations are involved in the cassava processing into various desired products, and these include peeling, washing, grating, boiling, parboiling, drying, milling, pressing, sieving, extrusion and frying. Before the cassava tuber is processed into any of its food and some of its non-food products, it must be peeled.

Peeling removes the cortex and the outer periderm layer adhering to it basically for product quality and reduction of cyanide content. For a root composed of $15 \%$ peel with a total cyanide content of $950 \mathrm{mg} / \mathrm{kg}$ (weight basis) and 35 $\mathrm{mg} / \mathrm{kg}$ in the flesh, $83 \%$ of the total cyanide is removed by peeling (Bencini, 1991) which is acceptable and safe for consumption. Ideally, and especially in the food industry, the peel must be completely removed without removing the useful tuber flesh for safe consumption and better quality of the end products. This justifies the need for improvement in mechanisation of cassava processing with special interest in the peeling process.

However, cassava peeling operations which obviously is the first post harvest processing operation in an attempt to commercially mechanise it has been faced with the challenges of preoperational treatment, geometric and morphological disparities in addition to other varying tuber properties. Thus, it is difficult to design an economically viable cassava peeling machine that is capable of peeling all roots from various varieties and sources with minimal useful tuber flesh wastage. To bridge the gap created by inefficient and low output of manual peeling process, mechanical peeling broadly achieved by either knife peeling principle (use of knife-like parts as peeling tools) or abrasive/attrition principle (use of frictional surfaces to cause wear) became inevitable

Numerous attempts made in development of peeling technology (Ezekwe, 1979; Nwokedi, 1984; Odigboh, 1983a; IITA, 2011; Akintunde et al., 2005, Olukunle, 2005; Oluwole, 2013), have been adversely characterised by drudgery of pre- operational activities of trimming, sorting, soaking and grading of tubers prior to peeling operation to mitigate for the afore mentioned design challenges and this consequently increases the processing cost and time Abrasive/attrition peeling concept exploited in cassava peeling model developed by Projects Development Institute (PRODA) though erroneously criticised and under rated by some researchers (Adetan, 2002 and Olukunle, 2013) possesses great prospects in eliminating these preoperational activities.

Their perceived inefficiencies could be attributed to some obvious design shortcomings and inappropriate design conception adopted. 
In order to address the issues associated with the mechanised cassava attrition peeling process, Edeh (2017) designed and developed a modified cassava attrition peeling machine (Figure 1.0) based on the attrition peeling concept with the introduction of breaker baffles, enhancement of inner peeling drum surface, introduction of egg shaped peeling balls which improved cassava peeling in quality and quantity, eliminated the drudgery of pre-operational treatment of trimming, slicing, sorting and grading of cassava tubers prior to peeling thereby reducing processing time and cost. Performance optimization of the developed modified cassava attrition peeling machine confirmed that the machine performs optimally with an efficiency of $88.7 \%$, throughput of $180 \mathrm{~kg} / \mathrm{hr}$, flesh loss of $5.49 \%$ and specific energy consumption of $58.4 \mathrm{~kJ} / \mathrm{kg}$ at an optimal peeling drum speed, cassava moisture content, mass of loaded cassava, number of peeling balls, geometric mean diameter and peel thickness of $45 \mathrm{rpm}, 85 \% \mathrm{~Wb}, 82 \mathrm{~kg}, 110,48 \mathrm{~mm}$ and $4.13 \mathrm{~mm}$ respectively (Edeh, 2017). The machine showed improved peeling time resulting in reduced cost of processing hence suitable for further economic analysis.
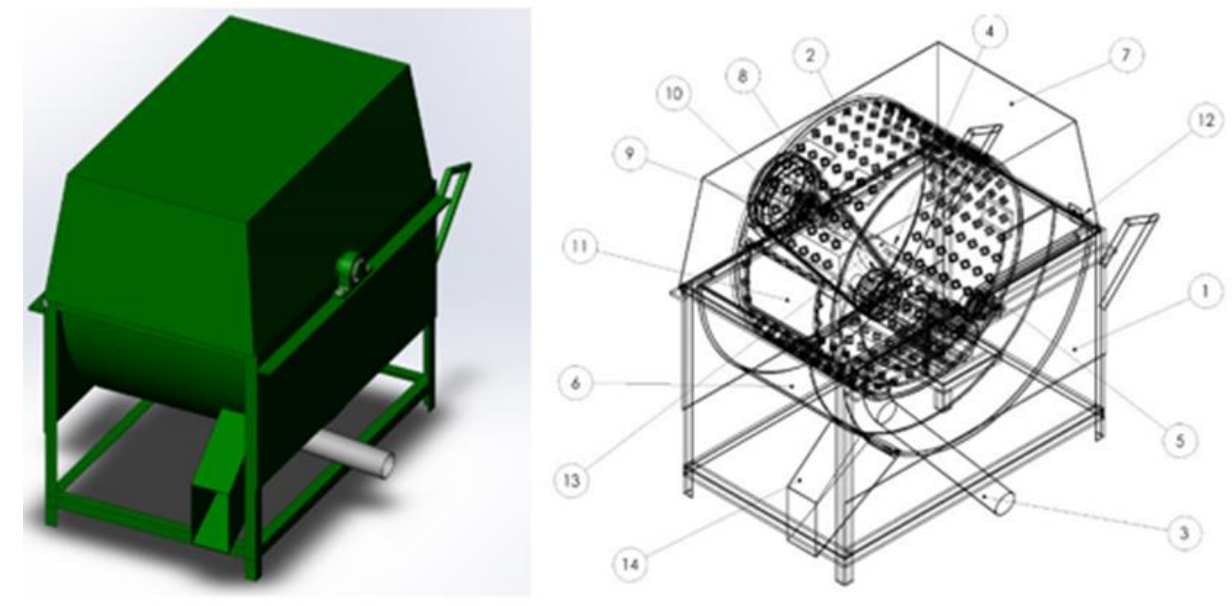

Figure 1. Modified Cassava Attrition Peeling Machine: 1.Structural Frame, 2. Peeling drum, 3. Discharge pipe, 4. Shaft, 5. Bearing, 6. Water bath(trough), 7. Covering hood, 8. Electric motor, 9.pulley, 10. Motor shaft, 11. Loading cover, 12. Hinges, 13.Bolt, 14. Discharge slit.

Despite the considerable improvement in the performance of the modified cassava attrition peeling machine, cassava processors and investors have remained sceptical in adopting this technology because most processors use initial capital (procurement) cost as the primary (and sometimes only) criteria for equipment selection (Oti and Lewachi, 2017) while most of the processors still rely on the manual peeling technique. Application of a benefit cost analysis will determine if an investment in this new peeling technology is profitable as well as provide a cost evaluation basis for comparing the modified cassava attrition peeling machine with existing peeling technology. Hence, in this study, the benefit cost analysis is used to explore the cost effectiveness and economic viability of adopting this modified cassava attrition peeling machine. 


\section{MATERIALS AND METHODS}

\section{Machine Description and Evaluation Parameters}

The detailed diagram and photograph of the modified cassava attrition peeling machine with egg. shaped peeling balls designed and developed by Edeh, 2017 are shown in Figure 1 and Plate 1 respectively. The principle of operation of the modified cassava attrition peeling machine is achieved by attrition which constitute the use of metal surfaces of roughened inner peeling drum and egg shaped peeling balls to cause abrasion with consequent removal of softer cassava tuber surface (the peel). In operation, a known mass of cassava for which other relevant properties are determined and estimated numbers of peeling balls are loaded through the gate into the peeling drum. The machine is energized through the prime mover causing a rotational motion of the drum.

The egg. shaped peeling balls together with the embossed inner surface of the drum causes the wearing of the cassava peel. Being a batch process operation, the cylindrical peeling drums impacts rotational motion on the balls freely mixed with the cassava and consequently creating tumbling effect in the drum that gives random relative motion hence effecting peeling. Material removed from the surface of the cassava by abrasion, which has the form of flake and also tiny particles in pulpy matter, sinks through the perforations of the drum to the bottom of the housing trough serving as water bath and also prevents the clogging of the balls.

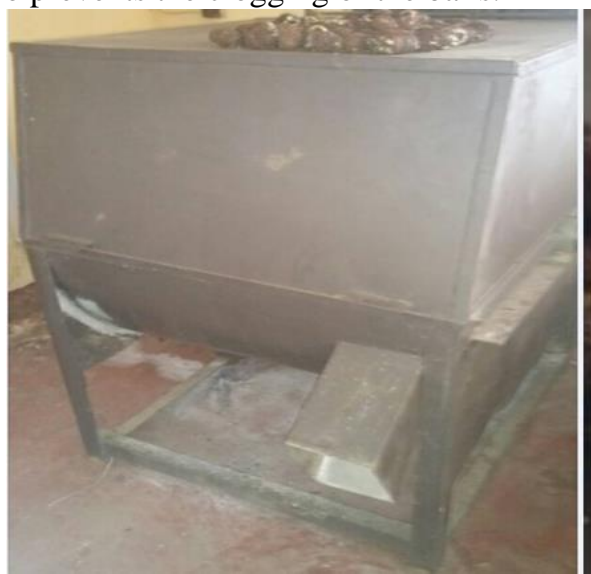

Plate 1: (a) Modified cassava attrition peeling machine

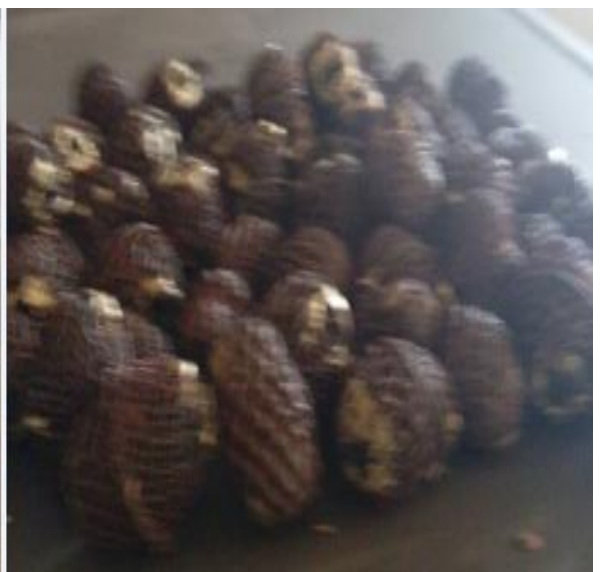

(b) Peeling Balls

Performance test indicators which aid in the analysis of the economic viability of the modified machine include the peeling efficiency, flesh loss, throughput, and specific energy consumption. Flesh loss is the amount of starchy flesh removed alongside the peels during peeling. Peeling efficiency is the ratio of the total mass of peel by the machine to mass of manual peel (theoretical mass of peel) while its throughput is the total mass of cassava peeled and discharged by the machine per unit time. 
Specific energy consumption of the machine is quantity of energy it used to peel a unit mass of cassava fed into it. The mathematical relationship used for computing the test indicators are shown in equations $1-4$ given by (Agrawal, 1987; Nwankwojike et al., 2016; Edeh, 2017).

$$
\begin{aligned}
F_{l} & =M_{c-}\left(m_{c p}+m_{p t}\right) \\
\eta_{p} & =\frac{M_{P c}}{M_{p r}+M_{p c}} \times \frac{100}{1} \\
T P & =\frac{M_{c}}{t} \\
S E & =\frac{P t}{M_{c}}
\end{aligned}
$$

Where $F_{l}=$ Tuber flesh loss $(\%), \eta_{p}=$ peeling efficiency $(\%), T P=$ throughput, $(\mathrm{kg} / \mathrm{h})$, and $S E=$ specific energy consumption $(\mathrm{kJ} / \mathrm{kg})$.

$\mathrm{m}_{\mathrm{cp}}=$ mass of the peeled cassava $(\mathrm{kg}), \mathrm{m}_{\mathrm{pt}}=$ theoretical mass of peel, $\mathrm{M}_{\mathrm{c}}=$ mass of the loaded cassava, $\mathbf{M}_{\mathrm{pc}}=$ mass of peel $(\mathrm{kg})$ collected through the peel outlet of machine and $\mathrm{M}_{\mathrm{pr}}=$ mass of peel removed by hand after machine peeling $(\mathrm{kg}), \mathrm{t}=$ Time taken $(\mathrm{s})$. $\mathrm{P}=$ Power consumed by the electric motor in $\mathrm{kW}$.

The benefits in adopting the improved cassava attrition peeling machine was also evaluated using the time taken to complete batch peeling process, amount charged for peeling in the various techniques, the average price per $\mathrm{kg}$ for peeling batch cassava mass, throughput capacity for the various batch mass of cassava and the total energy cost. Energy cost savings is evaluated using Equation (5).

$$
E C S=\frac{T E C_{\text {proda } / \text { Manual }}-T E C_{M C A P M}}{T E C_{\text {proda } / \text { Manual }}} \times 100
$$

Where:

ECS $=$ Energy cost savings,

$\mathrm{TEC}=$ Total Energy cost

The Benefit Cost Ratio, BCR of the modified machine was evaluated using Equation (6) by Gerald and Marta (2009).

$$
B C R=\frac{P V B}{P V C}
$$

Where the Present Value Cost,

$$
P V C=\sum_{t=1}^{T} \frac{B_{t}}{\left(1+r_{i}\right)^{t}}
$$

And the Present Value Benefit,

$$
P V B=\sum_{t=1}^{T} \frac{C_{t}}{\left(1+r_{i}\right)^{t}}
$$


$B_{t}$ and $C_{t}$ are the respective benefits and costs in time $\mathrm{t}$ and $r_{i}$ is interest rate $=13 \%$ (Daniel and Elisha, 2015).

\section{RESULTS AND DISCUSSION}

The improved machine charged $\$ 500$ per $80 \mathrm{~kg}$ batch mass of cassava while the existing and manual peeler charged $\$ 500$ per $60 \mathrm{~kg}$ and $20 \mathrm{~kg}$ batch mass respectively. The modified cassava attrition peeling machine (MCAPM) designed and fabricated using locally sourced material with egg shaped ball accessories and improved peeling surface features eliminated pre-operational treatment with $42.8 \%$ savings in processing time, $43 \%$ increase in peeling efficiency, $74.8 \%$ increase in throughput, $67 \%$ tuber flesh recovery and $10.6 \%$ reduction in specific energy consumption over the existing machine as shown in the performance graphs in Figure 2.

Since the peeling machines are powered electrically, the cost of generated electricity is taken into consideration to determine the energy cost of using the machines. Electrical cost from the national grid used to power the machines is at the rate of $\$ 30.93$ per $\mathrm{kWh}$ while energy cost for the manual peeler was considered as his wages per batch mass of cassava.

The analysis as shown in Table 1 reveals a decrease in the total energy cost in using the improved cassava attrition peeling machine as compared to the existing version and manual peeling process. In addition to its increased throughput capacity, the improved cassava attrition peeling machine performed optimally with a $12 \%$ and $69 \%$ energy cost savings than the existing and manual peeling process.
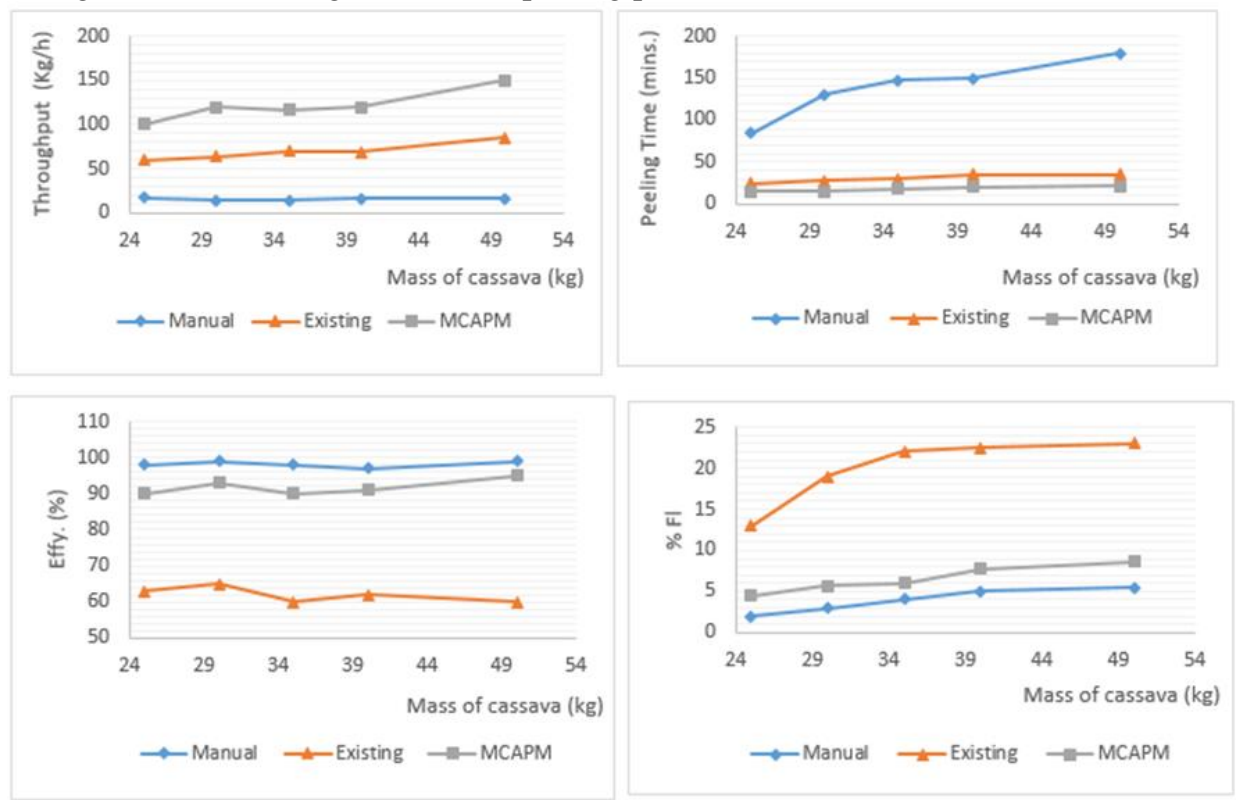

Figure 2. Performance Test Graphs 


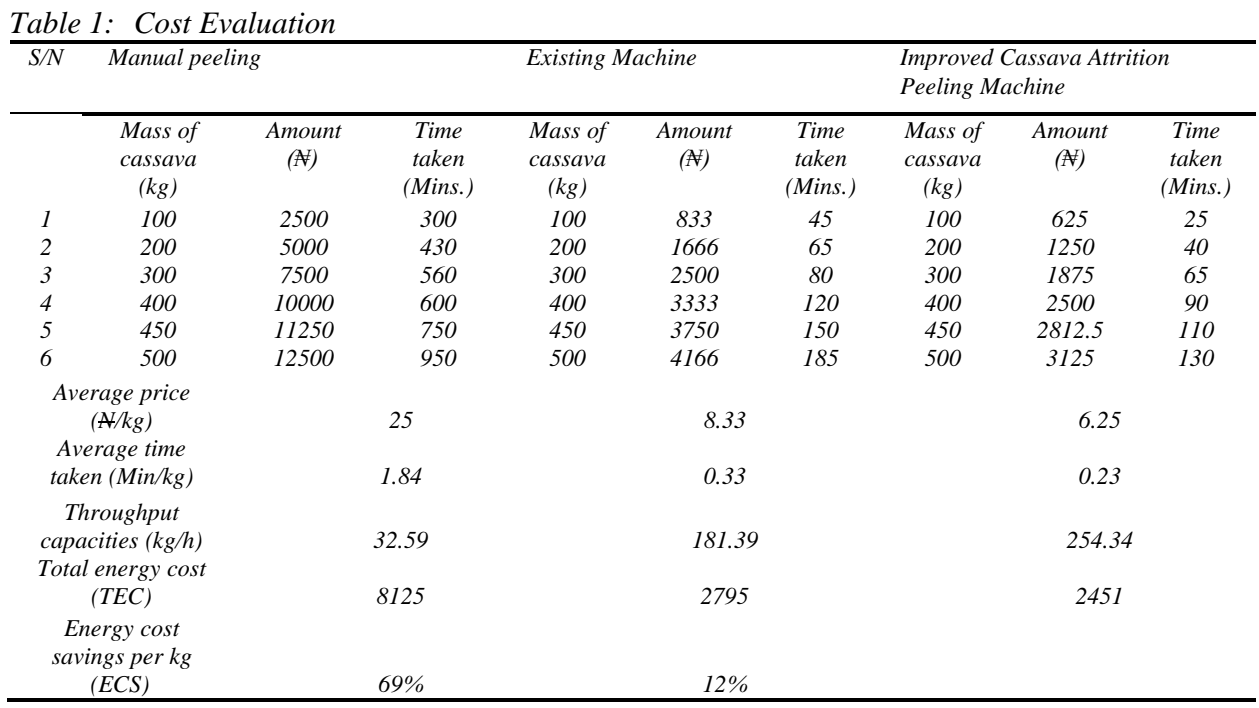

\section{Payback and benefit cost ratio analysis}

In the analysis of the payback period and cost benefit ratio of the existing (PRODA) and Modified cassava attrition peeling machines (Table 2), the following considerations were made.

1. The machines operate at 8 hours/day and 6 days/week, hence the machine operation time per year is 288 days/yr (2304 hrs/yr). If the maintenance time is taken as $24 \mathrm{hrs} / \mathrm{yr}$, thus the effective machine operation time is $2280 \mathrm{hrs} / \mathrm{yr}$.

2. The existing PRODA machine utilizes a total of $3728.5 \mathrm{~W}(\approx 3.73 \mathrm{KW})$ for its operation. Thus energy consumed per year is $8504.4 \mathrm{KWh}$. while the modified cassava attrition peeling machine (MCAPM) utilizes a total of $2237.1 \mathrm{~W}(\approx$ $2.23 \mathrm{~kW}$ ) for its operation. Thus its energy consumed per year is $5084 \mathrm{kWh}$ and as stated earlier PHCN charges $\$ 30.93$ per $\mathrm{kWh}$.

This result reveal a payback period of one year and four months for the modified machine while the existing PRODA version has a payback period of three years and nine months. Thus, the amount invested in this project will be recovered within this length of time with an average yearly cash inflow of 414,420 from just peeling cassava tubers.

The Benefit Cost Ratio, BCR of the modified machine tabulated in Table 3 was evaluated as 2.56 using Equation (6). This implies that for every $\mathbf{N} 1$ spent, a benefit of N2.56 was realized. The investment is therefore acceptable. 
Table 2: Payback period of the attrition machine.

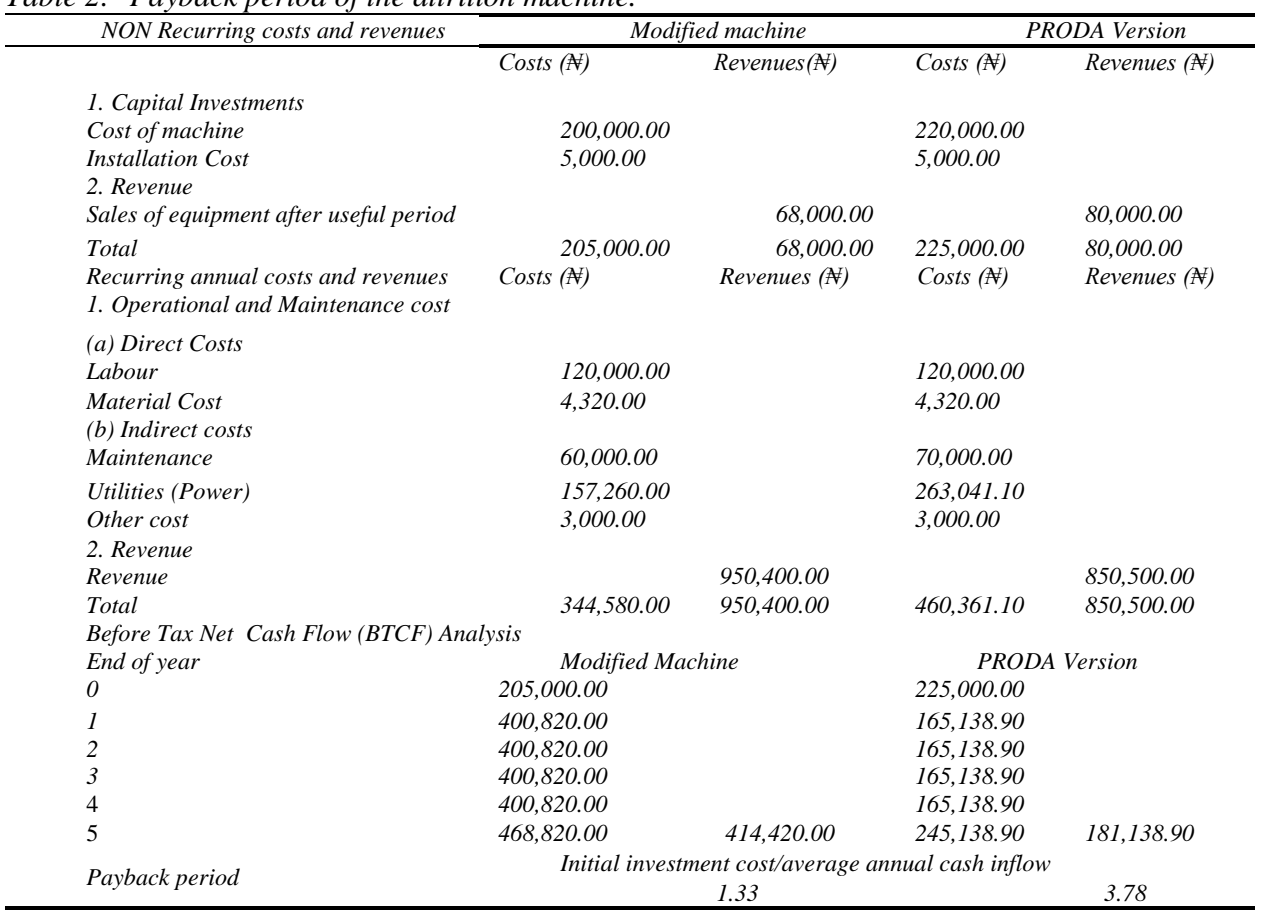

Table 3: Benefit-cost analysis of the modified cassava attrition peeling machine.

\begin{tabular}{|c|c|c|c|c|c|c|c|c|}
\hline$Y R$ & $\begin{array}{l}\text { Investment } \\
\text { Cost (\#) }\end{array}$ & $\begin{array}{l}\text { Operating } \\
\text { Cost (\#) }\end{array}$ & $\begin{array}{l}\text { Total Cost } \\
\text { (\#) }\end{array}$ & Sales (\#) & $\begin{array}{l}\text { Salvage } \\
\text { value } \\
\text { (A) }\end{array}$ & $\begin{array}{l}\text { Total Benefit } \\
\text { (\#) }\end{array}$ & $\begin{array}{l}\text { Present } \\
\text { Value } \\
\text { Benefit (\#) }\end{array}$ & $\begin{array}{l}\text { Present } \\
\text { Value } \\
\text { Cost (\$) }\end{array}$ \\
\hline \multirow[t]{2}{*}{0} & & & & & - & & & \\
\hline & $135,000.00$ & $344,580.00$ & $479,580.00$ & $950,400.00$ & & $950,400.00$ & $950,400.00$ & $479,580.00$ \\
\hline \multirow[t]{2}{*}{1} & & & & & - & & & \\
\hline & & $344,580.00$ & $344,580.00$ & $950,400.00$ & & $950,400.00$ & $841,061.95$ & $304,938.05$ \\
\hline \multirow[t]{2}{*}{2} & & & & & - & & & \\
\hline & & $344,580.00$ & $344,580.00$ & $950,400.00$ & & $950,400.00$ & $744,302.61$ & $269,856.68$ \\
\hline \multirow[t]{2}{*}{3} & & & & & - & & & \\
\hline & & $344,580.00$ & $344,580.00$ & $950,400.00$ & & $950,400.00$ & $658,674.87$ & $238,811.22$ \\
\hline \multirow[t]{2}{*}{4} & & & & & - & & & \\
\hline & & $344,580.00$ & $344,580.00$ & $950,400.00$ & & $950,400.00$ & $582,898.12$ & $211,337.37$ \\
\hline \multirow[t]{3}{*}{5} & & & & & $68,000.0$ & & & \\
\hline & & $344,580.00$ & $344,580.00$ & $950,400.00$ & 0 & $1,018,400.00$ & $552,746.72$ & $187,024.22$ \\
\hline & Total & & & & & & $4,330,084.27$ & $1,691,547.55$ \\
\hline
\end{tabular}

\section{CONCLUSION}

The modified cassava attrition peeling machine eliminated pre-operational treatment with $42.8 \%$ savings in processing time, $12 \%$ energy cost savings compared to the existing machine, $43 \%$ increase in peeling efficiency, $74.8 \%$ increase in throughput, $67 \%$ tuber flesh recovery and $10.6 \%$ reduction in specific energy consumption over existing machine. 
Its benefit cost analysis showed that the improved machine has a payback period of one year and four months with Benefit Cost Ratio, BCR of 2.56 hence a worthwhile investment.

Since peeling constitutes the major bottle neck in the processing cassava, Government and other agencies should grant loan to farmer so that they can afford to adopt this important innovation immediately for mass processing of cassava products to meet the growing demand of the Nigeria industries and for export.

\section{REFERENCES}

[1] Adekanye, T. A., Ogunjimi, S. I. and Ajala, A. O. (2013). An assessment of cassava processing plant in Irepodum Local Government Areas, Kwara State, Nigeria. World Journal of Agricultural Research, 1, pp.14-17.

[2] Adetan, D. A. (2002). Modeling of the mechanical peeling of cassava tubers. Ph.D. Thesis, Agricultural Engineering Department, Obafemi Awolowo University, Ile-Ife, Nigeria.

[3] Agrawal, Y. C. 1987. Ginger peeling machine parameters. Agricultural Mechanization in Asia. Africa and Latin America 18(2): pp.59-62.

[4] Akintunde, B. O., Oyawale, F. A and Tunde-Akintunde, T. Y. (2005). Design and fabrication of a cassava peeling machine. Nigerian Food Journal. Vol. 23, pp. $1-8$.

[5] Bencini, M.C. (1991). Post-harvest and processing technologies of African staple foods: a technical compendium. Agriculture Services bulletin No. 89., FAO, Rome.

[6] Daniel Magnowski and Elisha Bala-Gbogbo (2015).Nigerian Central Bank Holds Key interest Rate at 13\%. Bloomberg Newspaper. May 19, 2015. https://www.bloomberg.com/news/article/2015-05-19/nigerian-central-bank-holds-keyinterest-rate-at-13

[7] Edeh, J.C.,.(2017). Design modification and optimisation of a Cassava attrition peeling machines using Response surface methodology Ph.D Dissertation. Michael Okpara University of Agriculture, Umudike, Nigeria

[8] Egbeocha, C.C., Asoegwu, S.N and Okereke, N.A.A.(2016). A Review on Performance of Cassava Peeling Machines in Nigeria . Futo Journal Series (FUTOJNLS) Volume-2, Issue-1, pp. $140-168$.

[9] El-Sharkawy, M. A. and Cock, J. S. (1987). Response of cassava to water stress. Plant and Soil, 100, pp. 345-360.

[10] Ezekwe, G.O. (1979), Mechanising Cassava Peeling: The PRODA Cassava Nibbling Machine, PRODA Technical Reports No. 1, pp.1-20

[11] Gerald, Shively and Marta, Galopin. (2009). An overview of Benefit Cost Analysis. http://.www.agecon.purdue.edu/staff/shively/COURSES/AGEC406/reviews/bca.html, http://www.csir.org.gh

[12] IITA (International Institute of Tropical Agriculture) (2011). Research for Development (R4D) Review. Retrieved from http://r4dreview.org/wp-content/uploads/2011/11/ womenpeeling-cassava.

[13] Nwankwojike B.N., Onwuka O., Agwunwamba, C. J., Adama J. C. (2016) Mechanistic Models for predicting Specific energy consumption and throughput of palm nut-pulp separator. Applied Mathematical Modelling.

[14] Nwokedi, P. M (1984), Performance evaluation of cassava peeling machine. In: Tropical root crops: Production and uses in Africa, E.R Terry, E.U. Doku, O.B Arene and N.M Mahungu (Eds) Int. Development Res. Centre, pp. 108- 110. 
[15] Odigboh, E.U. (1983a). Cassava production, processing and utilization, In: Chan Jnr, H. T. (Ed.), Handbook of Tropical Foods, New York: Mercel Decker Pub. Inc., pp. 145-200.

[16] Olukunle, O.J. (2005). Development of a cassava peeling machine, Abstract, Proceedings of the International Conference on Global Food and Product Chain Dynamics, Innovations, Conflicts and strategies, 'Tropentag 2005', Univ. of Hohenheim Stuttgart, Germany, pp. 54.

[17] Olukunle, O. J. and Akinnuli, B. O. (2013). "Theory of an Automated Cassava Peeling System". International Journal of Engineering and Innovation Technology (Ijeit) Vol. 2, Issue 8, ISSN: 2277-3754 ISO 9001: 2008 Certified.

[18] Oluwole, O. O. and Adio, M. A. (2013). Design and Construction of a Batch Cassava Peeling Machine. Journal of Mechanical Engineering and Automation, 3(1): pp. 16-21

[19] Oti, F. O. and Lewachi A. A. (2017). Analysis of Economic Viability of Solar Photovoltaic Systems for Small Scale Off-grid Electricity Generation in Nigeria. Umudike Journal of Engineering and Technology (UJET). Vol. 3, No 1, June 2017. pp. 36 - 44.

[20] Ravindran, V. (1992). "Preparation of cassava leaf products and their use as animal feeds." FAO animal production and health paper (Rome, Italy: Food and Agriculture Organization of the United Nations) (95): 111-125. Retrieved 2010-08-13.

\title{
ANALIZA TROŠKOVA PRIMENE MODIFIKOVANE MAŠINE ZA LJUŠTENJE KOD MEHANIZOVANE OBRADE CASAVE
}

\author{
Edeh J. C $C^{* 1}$ and Lewachi A. A ${ }^{1}$ \\ ${ }^{1}$ Department of Mechanical Engineering, \\ College of Engineering and Engineering Technology, \\ Michael Okpara University of Agriculture, Umudike, Nigeria
}

Sažetak: U ovom radu su ocenjene prednosti usvajanja primene modifikovane mašine za ljuštenje kod mehanizovane obrade kasave (Manihot Esculenta). Parametri koji se procenjuju i upoređuju između modifikovane mašine za piling -ljuštenje kasave, postojećeg alata za ljuštenje i tehnike ručnog ljuštenja uključuju: specifičnu potrošnju energije, efikasnost ljuštenja, gubitak mase, propusni kapacitet mašine, period otplate i procenu troškova koristi.

Rezultati pokazuju da poboljšana - modifikovana mašina ima rok vraćanja troškova od jedne godine i četiri meseca, a odnos koeficijenta koristi i troškova (BCR) od 2,56.

Značajna poboljšanja parametara performansi mašine bila su evidentna sa povećanjem efikasnosti ljuštenja do $43 \%$, povećanje protoka zrna od $74,8 \%$, protokom mase od $67 \%$, sa uštedom troškova energije od $12 \%$ i smanjenja potrošnje specifične energije od 10,6\% u odnosu na postojeći aparat-uređaj za ljuštenje

Ključne reči: Modifikovana mašina za piling-ljuštenje kasave, rok otplate, procena troškova I koristi, ušteda troškova energije, parametari performansi.

*Corresponding Author. E-mail address.engredehjohnc@gmail.com 
Prijavljen:

Submitted:

Ispravljen:

Revised:

26.09.2019

Prihvaćen:

Accepted:

20.12.2019

31.01 .2020 